\title{
HUBUNGAN EKSPRESI CYCLOOXYGENASE-2 (COX-2) DENGAN DISEASE FREE SURVIVAL DAN OVERALL SURVIVAL PADA PENDERITA KANKER PAYUDARA
}

\section{THE RELATIONSHIP BETWEEN CYCLOOXYGENASE-2 (COX-2) EXPRESSION WITH DISEASE FREE SURVIVAL AND OVERALL SURVIVAL IN BREAST CARCINOMA}

\author{
Prihantono*, Zaenal Abidin, Muhammad Juhamran, \\ Haryasena, Salman Ardi Syamsu \\ Departmen Ilmu Bedah, Fakultas Kedokteran, Universitas Hasanuddin, Makassar, Sulawesi \\ Selatan, Indonesia, \\ Jl. Perintis Kemerdekaan Km. 11, Tamalanrea, Makassar, Indonesia
}

\begin{abstract}
ABSTRAK
Cyclooxygenase-2 (COX-2) berperan dalam pertumbuhan tumor dan metastasisnya yang berdampak pada buruknya prognosis. Tujuan penelitian ini untuk mengetahui hubungan ekspresi COX-2 terhadap disease free survival dan overall survival pada pasien kanker payudara. Penelitian ini bersifat observasional menggunakan desain kohort dengan periode follow up selama 24 bulan. Hasil penelitian ini menunjukkan ekspresi COX-2 ditemukan pada 21 sampel (42\%) dari 50 pasien kanker payudara. Selama follow up 24 bulan, lama disease free survival (DFS) pada COX-2 negatif (20,1 bulan) lebih lama dibandingkan pada COX-2 positif (14,0 bulan) dan menunjukkan hubungan yang signifikan ( $\mathrm{p}<0,01)$. Lama overall survival (OS) pada COX-2 negatif $(22,6$ bulan) lebih lama dibandingkan pada COX-2 positif (17,8 bulan) yang juga menunjukkan hubungan yang signifikan $(\mathrm{p}<0,01)$. Terdapat hubungan yang signifikan antara ekspresi COX-2 dengan DFS dan OS pada pasien kanker payudara. COX-2 bisa dijadikan salah satu faktor prognostik kanker payudara.
\end{abstract}

Kata kunci: cyclooxygenase-2, disease free survival, kanker payudara, overall survival

\begin{abstract}
Cyclooxygenase-2 (COX-2) plays a role in the growth and metastasis of tumor which affects the poor prognosis. The research aimed to investigate the relationship between Cox-2 expression and the disease free survival and overall survival on the breast cancer patients. This was the observational research using the longitudinal (Cohort) design with the follow-up period for 24 months. The research result indicates that COX-2 expression is found in 21 samples (42\%) out of 50 breast cancer patients. During 24 months follow up, DFS on the negative COX-2 expression (20,1 months) is longer than the positive COX-2 expression (14,0 months) and indicates the significant relationship ( $\mathrm{p}<0.01)$. OS on the negative COX-2 expression $(22,6$ months) is longer
\end{abstract}


than the positive COX-2 expression (17,8 months) which also indicates the significant relationship $(\mathrm{p}<0.01)$. There is a significant relationship between COX-2 expression with disease free survival and overall survival in breast cancer patients. COX-2 can be one of the useful prognostic factors of breast cancer.

Keywords: breast cancer, cyclooxygenase-2, disease free survival, overall survival

\author{
Penulis korespondensi: \\ Prihantono \\ Departmen Ilmu Bedah, \\ Fakultas Kedokteran, Universitas Hasanuddin \\ J1. Perintis Kemerdekaan KM. 11, Tamalanrea, Makassar, Indonesia \\ Email: prihantono.md@gmail.com
}

\title{
PENDAHULUAN
}

Kanker payudara merupakan jenis kanker yang sering ditemukan pada wanita dan menjadi penyebab paling umum kematian akibat kanker. Insidensi kanker payudara semakin meningkat dari tahun ke tahun baik secara global maupun nasional. Berdasarkan Globocan tahun 2012, insidensi kanker yang tertinggi di Indonesia adalah kanker payudara dengan jumlah 48.998 kasus (30,5\%), diikuti kanker serviks dengan kejadian 20.928 kasus (13,0\%) (Jemal et al., 2011; Sinaga, 2015). Data Surveillance Epidemiology and End Resulys (SEER) tahun 2007, terdapat 62.030 kanker in situ, 178.480 wanita didiagnosis menderita kanker payudara invasif dan lebih dari 40.000 wanita meninggal karena penyakit tersebut di Amerika Serikat. Angka kematian ini dapat ditekan jika terdapat cara untuk memprediksi perjalanan kanker payudara dan hasil dan respon terhadap terapi (Lester et al., 2005).

Patomekanisme kanker payudara sebagaimana kanker pada umumnya disebabkan oleh interaksi antara faktor genetik dan faktor lingkungan. Kanker terjadi akibat adanya abnormalitas pertumbuhan sel yang meliputi peningkatan proliferasi, angiogenesis dan penurunan apoptosis (Lester, 2010).

Salah satu faktor prediktif pada kanker payudara yang sedang banyak diteliti saat ini adalah protein COX-2. Ekspresi COX-2 pada human carsinogenesis masih kontroversi (Lester, 2010; Shim et al., 2003). COX-2 terlibat dalam karsinogenesis dan perkembangan tumor pada kanker. Baru-baru ini telah dilaporkan bahwa pada kanker payudara yang mengekspresikan COX-2 dan meningkatnya COX-2 pada jaringan dimungkinkan memiliki nilai prognostik. Pasien dengan COX-2 yang tinggi dapat menyebabkan kekambuhan lokal dan mengurangi terbebasnya dari penyakit yang berhubungan dengan harapan hidup (Rigas and Kashfi, 2005; Visscher et al., 2008).

Ristimaki et al., (2002) melakukan penelitian pada 1.576 pasien karsinoma payudara mendapatkan ekspresi berlebihan COX-2 berhubungan dengan prognosis buruk yaitu penurunan harapan hidup pasien. Dengan melihat protein COX-2 yang berperan pada karsinogenesis payudara di level molekuler merupakan hal yang penting bahwa data COX-2 berperan pada penatalaksanaan dan prognosis kanker payudara. Saat ini penelitian ekspresi COX-2 pada berbagai parameter kanker payudara masih menjadi kontroversi. Tujuan terapi kanker adalah untuk memberantas penyakit dan residu mikro-metastatiknya dengan tujuan untuk mencegah atau 
menunda kekambuhan. Standar waktu untuk menunjukkan kemanjuran terapi adalah peningkatan kelangsungan hidup secara keseluruhan, overall survival (OS). Kelangsungan hidup bebas penyakit, Disease free survival (DFS) merupakan titik akhir alternatif untuk OS. Meningkatnya DFS dan OS selalu menjadi tujuan terapi kanker (Gill S et al, 2006). Pada kanker, lamanya waktu setelah perawatan primer untuk kanker berakhir bahwa pasien bertahan tanpa tanda atau gejala kanker itu. Dalam uji klinis, mengukur DFS adalah salah satu cara untuk melihat seberapa baik terapi baru bekerja.

Penelitian COX-2 yang dihubungkan dengan DFS dan OS pada penderita kanker payudara di Makassar belum ada. Tujuan penelitian ini adalah untuk mengetahui hubungan ekspresi COX2 terhadap DFS dan OS pada pasien kanker payudara.

\section{METODE PENELITIAN}

\section{Lokasi dan Waktu Penelitian}

Penelitian ini dilakukan di divisi Bedah Onkologi, Departemen Ilmu Bedah, Rumah Sakit Dr. Wahidin Sudirohusodo Makassar. Pemeriksaan kspresi COX-2 dilakukan dengan metode immunohistokimia di Laboratorium Patologi Anatomi Fakultas Kedokteran Universitas Hasanuddin Makassar. Waktu penelitian dilaksanakan pada Maret 2015 sampai April 2017.

\section{Desain dan Variabel Penelitian}

Penelitian ini merupakan penelitian observasional dengan menggunakan metode longitudinal/kohort dengan follow up selama 2 tahun. Variabel penelitian terdiri atas : variabel terikat (DFS dan OS) dan variabel bebas (Cyclooxygenase-2).

\section{Populasi Penelitian}

Populasi penelitian adalah wanita penderita kanker payudara yang dirawat di divisi Bedah Onkologi, Departemen Ilmu Bedah, Rumah Sakit Dr. Wahidin Sudirohusodo Makassar. Kriteria inklusi penelitian adalah wanita penderita kanker payudara, tipe invasive ductal carcinoma, belum pernah mendapatkan terapi kanker. Kriteria eksklusi penelitian adalah tipe lobular karsinoma, mastitis karsinomatosa, menderita Infeksi saat pengambilan sampel. Pada penelitian ini terdapat 50 sampel yang memenuhi kriteria.

\section{Metode Pengumpulan Data}

Penderita kanker payudara yang memenuhi kriteria inklusi dicatat umur, tanda vital (frekuensi nadi, pernapasan, tekanan darah, suhu dan tingkat kesadaran), gejala klinik, faktor risiko, serta diagnosis klinisnya kemudian diberikan penjelasan mengenai tindakan operasi dan prosedur pemeriksaan patologi anatomi yang akan dilakukan. Sampel adalah jaringan yang diambil dari jaringan kanker penderita, dengan ukuran yang disesuaikan dengan stadium klinis wanita penderita kanker payudara. Jaringan tersebut selanjutnya dibawa ke Bagian Patologi Anatomi Rumah Sakit Dr. Wahidin Sudirohusodo Makassar untuk dilakukan pemeriksaan imunohistokimia ekspresi COX-2 menggunakan antibodi monoklonal Dako dan diamati dengan mikroskop cahaya binokuler merk Olympus tipe CX 21. Masing-masing sampel diperiksa oleh 2 orang ahli patologi anatomi. Kemudian diikuti selama 2 tahun setelah operasi dengan menilai adanya rekurensi, disease free survival dan overall survival. 


\section{HASIL DAN PEMBAHASAN}

Tabel I. menunjukan karakteristik pasien pada penelitian ini dimana didapatkan 50 sampel yang memenuhi kriteria. Pasien dengan umur kurang dari 50 tahun lebih banyak yaitu 27 pasien (54\%), dengan grading histopatologi terbanyak adalah moderate grade 22 pasien (44\%), stadium lokal lanjut lebih banyak yaitu 31 pasien (62\%) dan subtipe Luminal B yang didapatkan 17 pasien $(34 \%)$.

Tabel I. Karakteristik pasien

\begin{tabular}{lcc}
\hline \multicolumn{1}{c}{ Karakteristik } & Jumlah Pasien & $\%$ \\
\hline \hline Pasien & 50 & 100 \\
Ekspresi COX-2 & 21 & \\
$\quad$ Positif & 29 & 42,0 \\
$\quad$ Negatif & & 58,0 \\
Umur & 27 & \\
$\quad$ < 50 tahun & 23 & 54,0 \\
$\geq 50$ tahun & & 46,0 \\
Grading Histopatologi & 11 & \\
$\quad$ Low grade & 22 & 22,0 \\
$\quad$ Moderate grade & 17 & 44,0 \\
$\quad$ High grade & & 34,0 \\
Stadium & 8 & 16,0 \\
$\quad$ Dini & 31 & 62,0 \\
Lokal lanjut & 11 & 22,0 \\
$\quad$ Lanjut & & \\
Subtipe & 16 & 32,0 \\
$\quad$ Luminal A & 17 & 34,0 \\
Luminal B & 4 & 26,0 \\
Triple negative & 13 & \\
Overekspresi HER-2 & & \\
\hline \hline
\end{tabular}

Representasi mikrofotograf immunohistokimia COX-2 dari penelitian ini ditunjukkan pada Gambar 1. Menunjukkan hasil pemeriksaan IHC COX-2 negatif, tampak sitoplasma pucat, tidak terwarnai. Gambar 2. Hasil pemeriksaan IHC COX-2 positif, menunjukkan sitoplasma terwarnai coklat. 


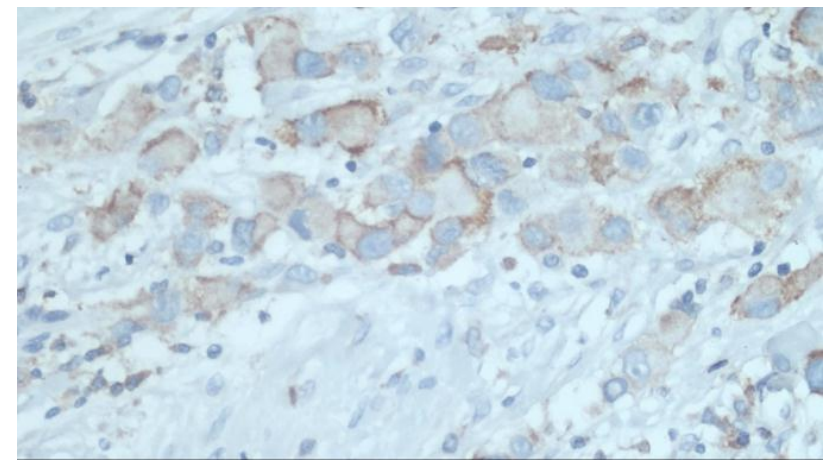

Gambar 1. Hasil pemeriksaan IHC dengan ekspresi Cox-2 negatif

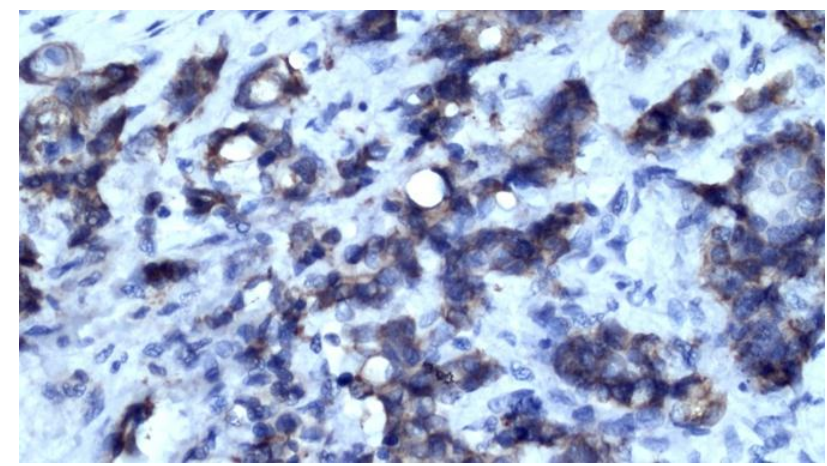

Gambar 2. Hasil pemeriksaan IHC dengan ekspresi Cox-2 positif

Tabel II. menunjukkan umur subyek yang diteliti adalah antara 32-81 tahun, dengan mean (rerata) 50 \pm 10 tahun. Secara umum, pada akhir follow-up 24 bulan didapatkan lama DFS semua subyek antara 1-24 bulan dengan mean 17,5 $\pm 7,7$ bulan. Sedangkan lama OS juga bervariasi antara 1-24 bulan dengan mean 20,6 $\pm 6,5$ bulan.

Tabel II. Statistik diskriptif umur, lama DFS dan OS $(n=50)$

\begin{tabular}{lcccc}
\hline \hline Variabel & Minimum & Maximum & Mean & SD \\
\hline Umur (tahun) & 32 & 81 & 50,34 & 10,085 \\
Lama DFS (Bulan) $^{1}$ & 1 & 24 & 17,54 & 7,667 \\
Lama OS (Bulan) $^{2}$ & 1 & 24 & 20,60 & 6,547 \\
\hline \hline
\end{tabular}


Tabel III. menunjukkan sebagian besar subyek berumur 40-49 tahun (46,0\%). Berdasarkan ekspresi COX-2, didapatkan 21 subyek positif (42,0\%) dan 29 negatif $(48,0 \%)$. Berdasarkan status DFS dan OS pada akhir follow-up, didapatkan DFS sebanyak 24 subyek (48,0\%) dan OS sebanyak 35 subyek $(70,0 \%)$.

Tabel III. Sebaran umur, COX-2, DFS dan OS $(n=50)$

\begin{tabular}{llcc}
\hline \hline Variabel & Kategori & n & \% \\
\hline \hline Umur & $<40$ tahun & 4 & 8,0 \\
& $40-49$ tahun & 23 & 46,0 \\
& 50-59 tahun & 16 & 32,0 \\
& 60-69 tahun & 5 & 10,0 \\
& $>=70$ tahun & 2 & 4,0 \\
\hline Ekspresi COX-2 & Negatif & 29 & 58,0 \\
& Positif & 21 & 42,0 \\
\hline DFS $^{1}$ & Ya & 24 & 48,0 \\
& Tidak & 26 & 52,0 \\
\hline OS $^{2}$ & Ya & 35 & 70,0 \\
& Tidak & 15 & 30,0 \\
\hline \hline
\end{tabular}

Tabel IV. menunjukkan perbandingan rerata lama DFS antara COX-2 negatif dengan positif, dimana terlihat rerata lama DFS pada COX-2 negatif (20,1 bulan) lebih lama dibandingkan pada COX-2 positif (14,0 bulan). Hal ini menunjukkan adanya hubungan signifikan antara COX2 positif dengan lama DFS yang lebih singkat (sekitar 6 bulan) dibandingkan COX-2 negatif $(\mathrm{p}<0,01)$.

Tabel IV. Mean survival time DFS

\begin{tabular}{cc|c|cc}
\hline \hline & \multicolumn{3}{c}{ Mean } \\
\cline { 3 - 5 } & & & \multicolumn{2}{c}{$\mathbf{9 5 \%}$ Confidence Interval } \\
\cline { 3 - 5 } COX-2 & Estimate & Std. Error & Lower Bound & $\begin{array}{c}\text { Upper } \\
\text { Bound }\end{array}$ \\
\hline Negatif & 20,103 & 1,137 & 17,875 & 22,331 \\
Positif & 14,000 & 1,743 & 10,583 & 17,417 \\
Overall & 17,540 & 1,073 & 15,436 & 19,644 \\
\hline \hline
\end{tabular}

Gambar 3. memperlihatkan probabilitas DFS pada COX-2 negatif lebih tinggi dibandingkan dengan COX-2 positif, yang berarti kemungkinan DFS pada subyek dengan COX2 negatif lebih tinggi dibandingkan subyek dengan COX-2 positif. 


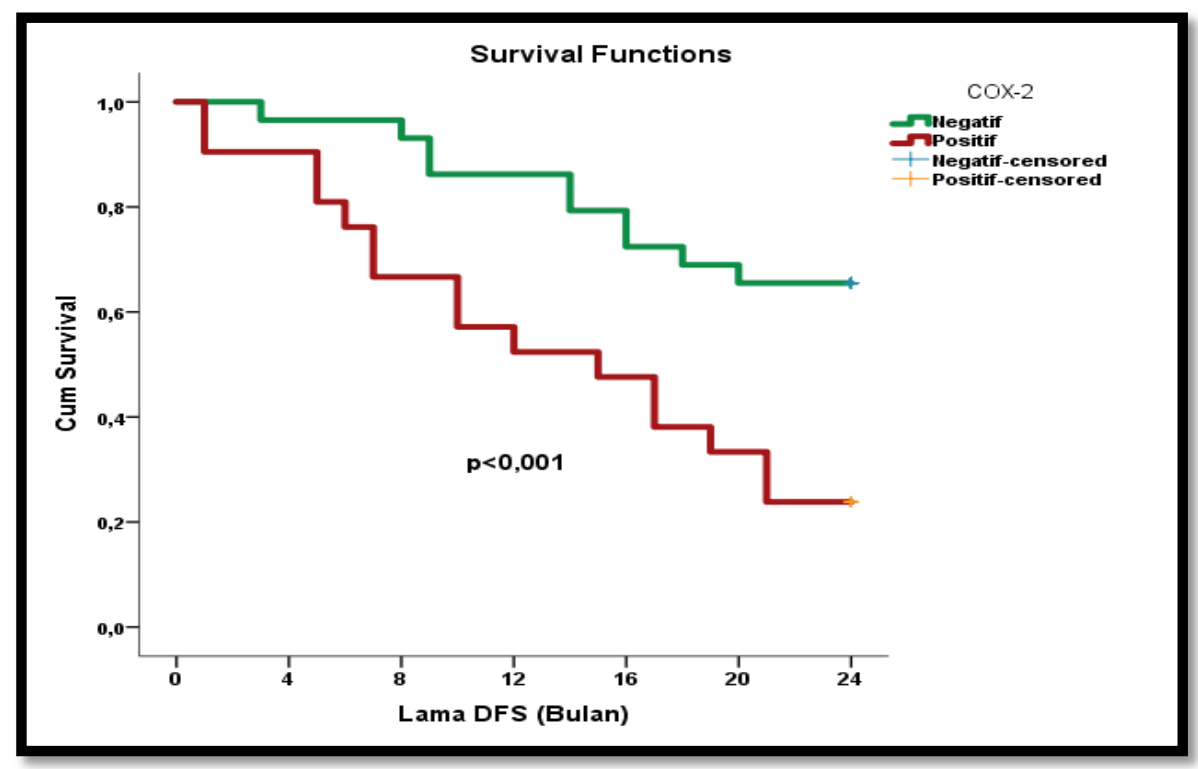

Gambar 3. Perbandingan proporsi DFS menurut COX-2

Tabel V. menunjukkan perbandingan rerata lama OS antara COX-2 negatif dengan positif, dimana terlihat rerata lama OS pada COX-2 negatif (22,6 bulan) lebih lama dibandingkan pada COX-2 positif (17,8 bulan). Hal ini menunjukkan adanya hubungan signifikan antara COX-2 positif dengan lama OS yang lebih singkat (sekitar 4,8 bulan) dibandingkan COX-2 negatif $(\mathrm{p}<0,01)$.

Tabel V. Mean survival time OS

\begin{tabular}{cc|c|cc}
\hline \hline \multirow{2}{*}{ COX-2 } & \multicolumn{3}{|c}{ Mean } \\
\cline { 3 - 5 } & \multirow{2}{*}{ Estimate } & Std. & \multicolumn{2}{c}{$\mathbf{9 5 \%}$ Confidence Interval } \\
\cline { 4 - 5 } & & Error & Lower Bound & Upper Bound \\
\hline Negatif & 22,621 & 0,669 & 21,309 & 23,933 \\
Positif & 17,810 & 1,808 & 14,266 & 21,353 \\
Overall & 20,600 & 0,917 & 18,804 & 22,396 \\
\hline \hline
\end{tabular}

Gambar 4. di bawah memperlihatkan Gambar probabilitas OS pada COX-2 negatif lebih tinggi dibandingkan dengan COX-2 positif, yang berarti kemungkinan OS pada subyek dengan COX-2 negatif lebih tinggi dibandingkan subyek dengan COX-2 positif. 


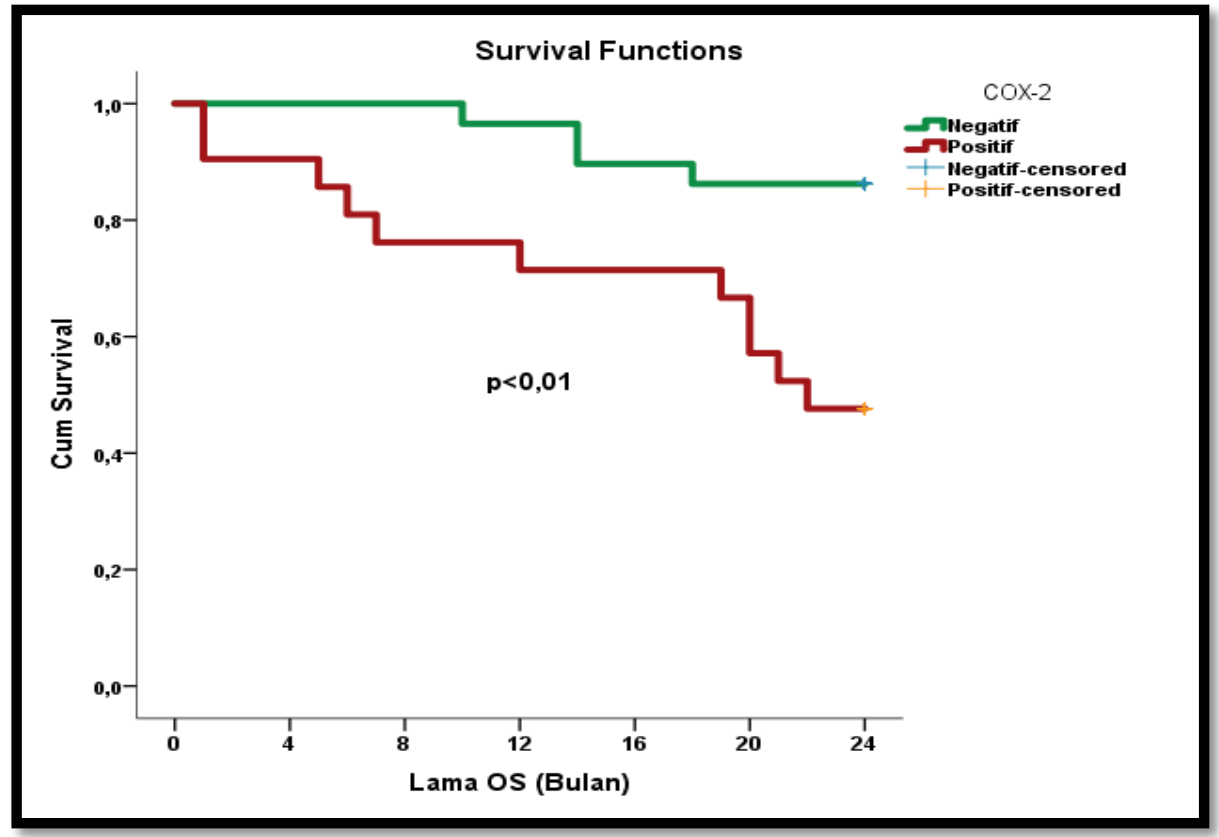

Gambar 4. Perbandingan proporsi OS menurut COX-2

Angka kejadian kanker payudara meningkat pada wanita usia di bawah 50 tahun. Umur rata-rata pasien saat diagnosis adalah 61 tahun pada perempuan kulit putih, 56 tahun pada Hispanik, dan 46 tahun pada perempuan Afrika-Amerika. Kasus kanker payudara sangat jarang terjadi sebelum umur 25 tahun (Lester, 2010). Penelitian yang dilakukan oleh Suchak K dkk (2014) menemukan prosentase COX-2 secara signifikan lebih tinggi pada kelompok usia >50 tahun. Umur subjek penelitian tidak berpengaruh terhadap ekspresi COX-2 pada kanker payudara baik analisis secara bivariat maupun multivariat dilihat dari distribusi penyebaran kasus. Pada penelitian ini dari semua kasus, umur penderita kanker payudara terbanyak adalah pada kelompok umur $<50$ tahun dengan jumlah 27 kasus (54\%) dengan usia minimun 32 tahun dan maksimal 81 tahun dengan rata-rata umur pasien adalah 50,34 tahun. Umur penderita pada penelitian ini relatif lebih muda apabila dibandingkan dengan umur penderita kanker payudara invasif di negara- negara barat, dimana $80-90 \%$ penderitanya adalah berumur diatas 60 tahun (Lester, 2010).

COX-2 memediasi produksi prostaglandin dan tromboksan dari asam arakidonat. Pada jaringan payudara ekspresi COX-2 dapat dijumpai pada sel epitel, makrofag yang teraktivasi dan sel tumor. Ekspresi COX-2 pada kanker payudara berperan dalam berbagai proses karsinogenesis seperti meningkatkan proliferasi sel, menekan apoptosis, meningkatkan kemampuan invasi dan meningkatkan kemampuan metastasis (Divvela et al., 2010).

Jalur COX-2 pada mekanisme karsinogenesis kanker payudara invasif melalui empat jalur. Jalur pertama melalui peningkatan ekspresi prostaglandin E2 (PGE2). Peningkatan jumlah PGE2 akan menyebabkan terjadinya peningkatan jumlah protein Vascular endothelial growth factor (VEGF), yang menyebabkan peningkatan kemampuan pembentukan pembuluh darah baru dan metastasis sel ganas. Disamping itu peningkatan jumlah PGE2 menyebabkan peningkatan ekspresi 
protein anti apoptosis yaitu B-cell lymphoma 2 (BCL2), menyebabkan penekanan terhadap protein pro apoptosis yaitu BCL2 associated X (BAX) dan melemahkan signal nitride oxyde (NO). Sebagai akibatnya kematian sel tidak terjadi dan sel ganas terus berproliferasi untuk berkembang (Divvela et al., 2010; Prihantono et al 2017). Jalur kedua, peningkatan ekspresi COX-2 akan menyebabkan stimulasi terhadap CD44. Dimana CD44 ini dapat mengaktifkan enzim matrix metalloproteinase 2 (MMP2), yang berakibat matrix ekstraseluler akan terdegradasi, sehingga sel ganas akan lebih mudah untuk melakukan invasi ke jaringan sekitar. Jalur ketiga, peningkatan ekspresi COX-2 akan mengaktivasi endoplasmic reticulum (ER), yang akan meningkatkan komplek estrogen dan ER. Komplek ini kemudian berikatan pada tempat yang spesifik pada DNA sel, dan ikatan ini akan memacu transkripsi kedalam mRNA, kemudian terbentuklah protein. Protein tersebut kemudian menyebabkan pertumbuhan dan perkembangan sel epitel payudara normal maupun ganas meningkat. Jalur keempat, peningkatan ekspresi COX-2 juga akan menyebabkan peningkatan metabolisme asam arakhidonat sehingga akan menyebabkan terbentuknya mutagen baru (Divvela et al., 2010).

Beberapa penelitian saat ini melaporkan bahwa peningkatan level ekspresi COX-2 berhubungan dengan meningkatnya risiko relaps dan kematian pada penderita kanker payudara berdasarkan analisa univariat (Nes et al., 2011). Pada penelitian ini didapatkan rerata lama DFS dan OS pada COX-2 negatif lebih lama dibandingkan dengan COX-2 positif dengan nilai masingmasing $\mathrm{p}<0,01$ yang menunjukkan adanya hubungan signifikan antara COX-2 positif dengan lama DFS dan OS yang lebih singkat dibandingkan COX-2 negatif. Hasil ini menunjukkan bahwa ekspresi COX-2 yang meningkat menghasilkan angka survival yang buruk.

Hasil penelitian yang serupa didapatkan oleh Van Nes et al (2011) dengan analisis univariat mendapatkan ekspresi yang tinggi dari COX-2 menghasilkan DFS yang buruk $(\mathrm{p}=0,02)$ dan lebih banyak kematian ( $\mathrm{p}=0,016)$ (Nes et al., 2011). Ristimaki et al (2002) melaporkan bahwa ekspresi COX-2 merupakan faktor survival negatif untuk distant disease free survival, didefinisikan sebagai waktu antara diagnosis dan kemunculan metastase diluar area lokoregional atau kematian akibat kanker payudara (Denkert et al., 2003). Berdasarkan analisis survival univariat oleh Denkert et al menemukan bahwa pengaruh prognostik dari ekspresi COX-2 sangat kuat terhadap DFS $(\mathrm{p}=0,0007)$ dan OS $(\mathrm{p}=0,02)$. Hasil yang diperoleh menunjukkan bahwa ekspresi COX-2 merupakan faktor prognostik yang independen untuk hasil yang tidak baik pada pasien dengan kanker payudara (Denkert et al., 2003). Peningkatan ekspresi protein COX-2 lebih sering pada kanker payudara yang menunjukkan marker untuk prognosis yang jelek dan berhubungan secara signifikan dengan penurunan angka survival (Ristimaki et al., 2002). Costa et al., (2002) pada penelitiannya terhadap 26 pasien yang difollow up selama 24 bulan menemukan bahwa pasien kanker payudara dengan tumor positif COX-2 memiliki angka DFS lebih pendek yang signifikan $(\mathrm{p}=0,0325)$.

Park et al., (2006). dalam penelitiannya terhadap 178 pasien kanker payudara selama periode median follow up 56 bulan menemukan bahwa DFS dan OS pada pasien dengan tumor yang mengekspresikan COX-2 secara signifikan menurun ketika dibandingkan terhadap pasien dengan tumor COX-2 negatif ( $\mathrm{p}=0,009$ pada DFS, $\mathrm{p}=0,011$ pada OS). Penurunan angka survival pada pasien dengan tumor yang mengekspresikan COX-2 sepertinya berhubungan dengan produksi PGE2. Peningkatan produksi PGE2 dihubungkan dengan proses inflamasi dan angiogenesis. 


\section{KESIMPULAN}

Terdapat hubungan yang signifikan antara ekspresi COX-2 dengan DFS dan OS pada pasien kanker payudara selama follow up 24 bulan. Hal ini menunjukkan bahwa ekspresi COX-2 yang meningkat menghasilkan angka survival yang buruk. Jumlah sampel yang masih relatif sedikit dan waktu follow up yang relatif pendek merupakan keterbatasan dalam penelitian ini.

\section{UCAPAN TERIMAKASIH}

Penulis mengucapkan terimakasih kepada seluruh pimpinan dan staf divisi Bedah Onkologi Fakultas Kedokteran Unhas/Rumah Sakit Dr. Wahidin Sudirohusodo, Makassar yang telah membantu penulis melaksanakan penelitian ini.

\section{DAFTAR PUSTAKA}

Costa, C., Soares, R., Reis-Filho, J., Leitao, D., Amendoeira, I., Schmitt, F. 2002. Cyclo-oxygenase 2 expression is associated with angiogenesis and lymph node metastasis in human breast cancer. J. Clin. Pathol 55: 429-34.

Denkert, C., Winzer, K.J., Muller, B.M., Weichert, W., Pest, S., Kobel, M., Kristiansen, G., Reles, A., Siegert, A., Guski, H., Hauptmann, S. 2003. Elevated expression of cyclooxygenase-2 is a negative prognostic factor for disease free survival and overall survival in patients with breast carcinoma. Cancer 97: 2978-2987.

Deshayes, F. 2005. Angiogenesis receptors: a new role in cancer. J Clin Endocrinol Metab 16: 293-299.

Divvela, A.K., Challa, S.R., \& Tagaram, I.K. 2010. Pathogenic role of cyclooxygenase-2 in cancer. Journal of Health Science 56: 502-516.

Gill, S. and Sargent, D. 2006. End points for adjuvant therapy trials: has the time come to accept disease-free survival as a surrogate end point for overall survival? The oncologist 11(6): 624-629.

Jemal, A., Bray, F., Center, M.M., Ferlay, J., Ward, E., Forman, D. 2011. Global cancer statistics. CA: a cancer journal for clinicians 61(2): 69-90.

Lester, S.C., Bae, J.W., Woo, S.U., Kim, H. \& Kim, C.H. 2005. The Breast. in: Kumar V, Abbas AK, Fausto N, Aster JC, eds. Robbin and Cotran's Pathology Basic of Diseases. Philadelphia: Saunders Elsevier.

Lester, S.C. 2010. Acute and Cronic Inflamation. in: Kumar V, Abbas AK, Fausto N, Aster JC, eds. Robbins and Cotran Pathologic Basis of Disease. Professional Edition: Expert Consult-Online. Philadelphia: Saunders Elsevier.

Nes, J.G., Kruijf, E.M., Faratian, D., Velde, C.J., Putter, H., Falconer, C., Smit, V.T., Kay, C., Vijver, M.J., Kuppen, P.J., Bartlett, J.M. 2011. COX2 Expression in prognosis and in prediction to endocrine therapy in early breast cancer patients. Breast Cancer Res Treat 125: 671-685.

Park, K., Han, S., Shin, E., Kim, H.J. \& Kim, J.Y. 2006. Cox-2 expression on tissue microarray of breast cancer. Eur J Surg Oncol 32(10): 1093-1096. 
Prihantono, P., Binekada, C., Hatta, M., Sampepajung, D., \& Islam, A.A. 2017. Correlation of BCL-2 and ER $\alpha$ mRNA expression with the clinical chemotherapeutic response in breast cancer. J. Med Sci 17(1): 31-37.

Rigas, B. \& Kashfi, K. 2005. Cancer prevention: a new era beyond cyclooxygenase-2. Journal of Pharmacology and Experimental Therapeutics 314: 1-8.

Ristimäki, A., Sivula, A., Lundin, J., Lundin, M., Salminen, T., Haglund, C., Joensuu, H. \& Isola, J. 2002. Prognostic significance of elevated cyclooxygenase-2 expression in breast cancer. Cancer Research 62: 632-635.

Shim, V., Gauthier, M.L., Sudilovsky, D., Mantei, K., Chew, K.L., Moore, D.H., Cha, I., Tisty, T.D. \& Esserman, L.J. 2003. Cyclooxygenase-2 expression is related to nuclear grade in ductal carcinoma in situ and is increased in its normal adjacent epithelium. Cancer Research 63: 2347-2350.

Sinaga, E.S. 2015. Analisis Ketahanan Hidup 5 Tahun pada Penderita Kanker Payudara di RS Sardjito Propinsi Yogyakarta-Indonesia. Program Pascasarjana Fakultas Kedokteran Universitas Gadjah Mada. Yogyakarta.

Suchak, K. 2014. Prognostic significance of cyclooxygenase-2 (COX-2) expression in patient with breast cancer. J. Clin. Pathology 79: 213-216.

Van Nes, J.G., de Kruijf, E.M., Faratian, D., van de Velde, C.J., Putter, H., Falconer, C. 2011. COX2 expression in prognosis and in prediction to endocrine therapy in early breast cancer patients. Breast cancer research and treatment 125(3): 671-685.

Visscher, D.W., Pankratz, V.S., Santisteban, M., Reynolds, C., Ristimäki, A., Vierkant, R.A., Lingle, W.L., Frost, M.H. \& Hartmann, L.C. 2008. Association between cyclooxygenase2 expression in atypical hyperplasia and risk of breast cancer. Journal of the National Cancer Institute 100: 421-427. 